\title{
Use and potential of nanotechnology in cosmetic dermatology
}

\author{
Pierfrancesco Morganti \\ Department of Dermatology \\ and Venereal Diseases, II University \\ of Naples, Naples, Italy
}

This article was published in the following Dove Press journal:

Clinical, Cosmetic and Investigational Dermatology

23 February 2010

Number of times this article has been viewed

\begin{abstract}
Biotechnology and nanotechnology are the key technologies of the twenty-first century, having enormous potential for innovation and growth. The academic and industrial goals for these technologies are the development of nanoscale biomolecular substances and analytical instruments for investigating cell biology at the cellular and molecular levels. Developments in nanotechnology will provide opportunities for cosmetic dermatology to develop new biocompatible and biodegradable therapeutics, delivery systems and more active compounds. Cosmetics have the primary function of keeping up a good appearance, changing the appearance, or correcting body odors, while maintaining the skin and its surroundings in good conditions. Thus cosmetic dermatology, recognizing the new realities of skin care products, has to emphasize the functional aspects of cosmetics through an understanding of their efficacy and safety in promoting good health. Nanoscience may help the scientific community to find more innovative and efficacious cosmetics. Understanding the physical model of the cell as a machine is essential to understand how all the cell components work together to accomplish a task. The efficacy and safety of new nanomaterials has to be deeply studied by ex vivo tests and innovative laboratory techniques. New delivery systems and natural nanocompounds, such as chitin nanofibrils for wound healing, are being used in cosmetic dermatology with good results, as are nanostructured $\mathrm{TiO}_{2}$ and $\mathrm{ZnO}$ sunscreens. The challenge is open.
\end{abstract}

Keywords: nanotechnology, nanobiotechnology, delivery systems, chitin nanofibrils, $\mathrm{TiO}_{2}, \mathrm{ZnO}$

\section{The significance of nanotechnology and nanobiotechnology}

Nanotechnology is a relatively young discipline. Today nanotechnology is not only essential for marketing-oriented chemical companies, but also a tool for developing science-based solutions for innovative therapeutics and cosmetics, enhancing well-being and addressing anti-aging issues. ${ }^{1}$ Nanotechnology is defined as the study of matter on an atomic or molecular scale. Generally, nanotechnology deals with structures the exact size and shape of which must be measured on a nanometric scale..$^{2-4}$ A nanometer $(\mathrm{nm})$ is one billionth of a meter (ie, $10^{-9}$ ) and typical atoms are about one third of a nanometer. In comparison the medial thickness of a human hair is about $10000 \mathrm{~nm}$ and an influenza virus has a diameter of $100 \mathrm{~nm}$ (see Figure 1). Nanobiotechnology, the interface between nanotechnology and biotechnology, is the branch of nanotechnology that deals with its biological and biochemical applications or uses.
Correspondence: Pierfrancesco Morganti Via Innocenzo XI, 4I, 00165 Roma, Italy Tel $+39(0) 692862626$

$\mathrm{Fax}+39(0) 69281523$

Email morganti@iscd.it 


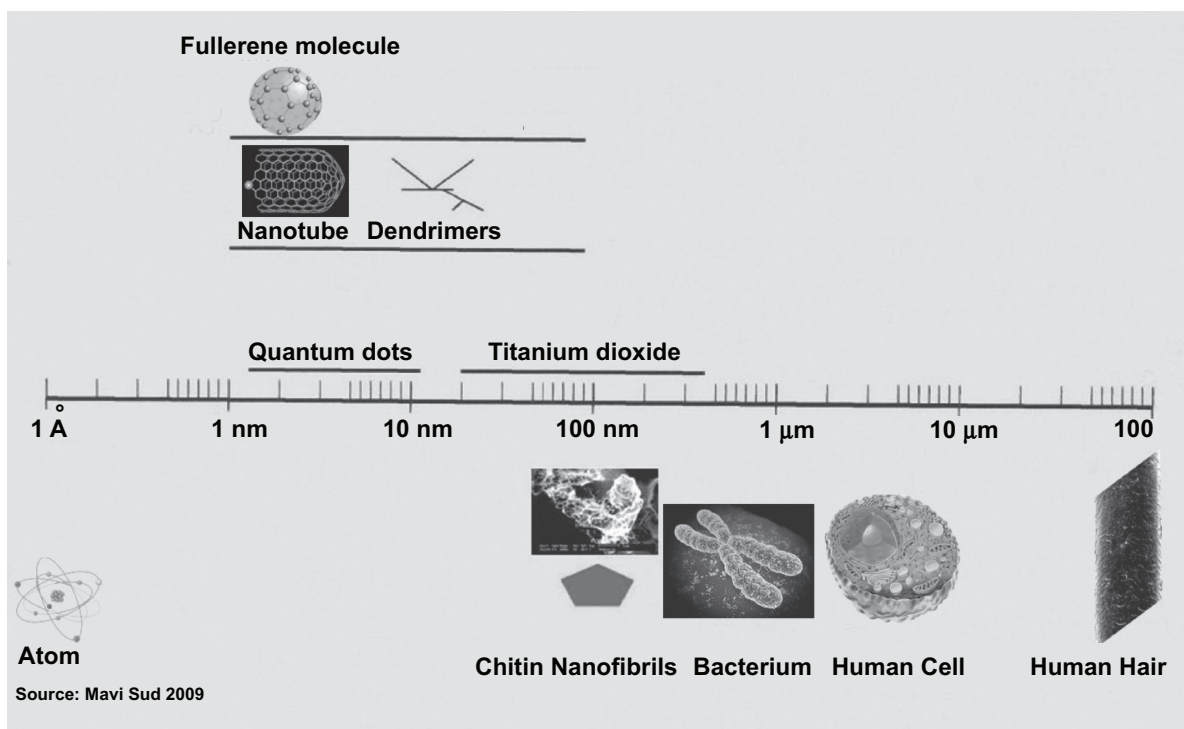

Figure I The nanometer dimension.

Nanotechnology is thus the set of methods and techniques for processing matter on atomic and molecular scales to create products with both special and improved chemico-physico features compared to conventional products. ${ }^{5}$ Therefore, the goal of nanobiotechnology is the development of nanoscale biomolecular components and analytical instruments for the investigation of cell biology at both the cellular and molecular levels.

\section{The expectations}

The potential uses and benefits together with the expectations of nanosciences are enormous. Accordingly, the European Commission (EU) supports the new nanotechnologies through its seventh framework program (Figure 2). Thus, the use of nanomaterials in cosmetic dermatology is the subject of intense debate in the EU, and efforts to establish fundamental rules for their use and risk assessment are ongoing throughout universities, government laboratories and industry. Investment of public funds in basic nanotechnology research has increased, which has, in turn, heightened the interest of private industry in developing patented products. ${ }^{6}$ The nanoscale production of a raw material may not only reduce costs, but also enhance its properties. In the biomedical and cosmetic fields nanotechnology has enormous potential, and nanobiotechnological methods are already being used in both medicine and the pharmaceutical industry.

For all these reasons, the International Organization for Standardization (ISO) ${ }^{7}$ is developing uniform standards for nanotechnology and supporting innovation, research and development, including appropriate risk assessment research, in this innovative field.

However, to obtain nanoscale materials a combination of physical micro-nanoelectronic, chemical and biological technologies are necessary. Currently, the three main areas of development include the following: ${ }^{8}$

nanomaterials: building specialized structures whose dimensions are controlled on a nanoscale;

nanobiotechnology: the manipulation of living systems using nanoscale engineering;

nanoelectronics: the development of microelectronics for devices such as radio frequency identification.

\section{Nanomaterials in cosmetic dermatology}

Nanomaterials and nanobiotechnology have the potential to radically change the way cosmetics and drugs deliver their benefits. Specifically, nanoparticles are being developed to encapsulate a wide range of ingredients benefical to the skin.

To obtain nanoparticles, two principles approaches are used:

a) the bottom-up method in which nanoparticles are assembled from the molecular dimension

b) the top-down approach that reduces larger particles by the use of chemico-physico methods. In cosmetics the top-down approach is more commonly used to produce different kind of structures. Examples of such structures include nanosomes, cubosomes, niosomes, and liposomes. 


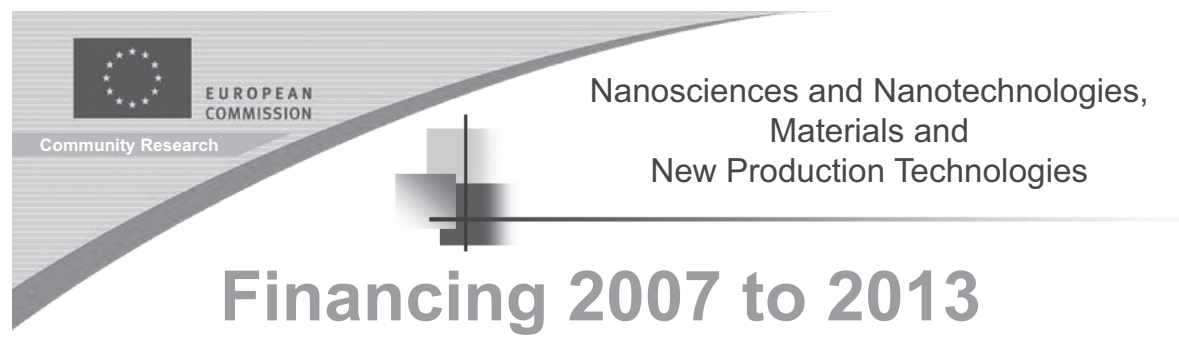

- Budget increase to approximately 3.5 Billion Euros

- Increase in real terms is about $40 \%$

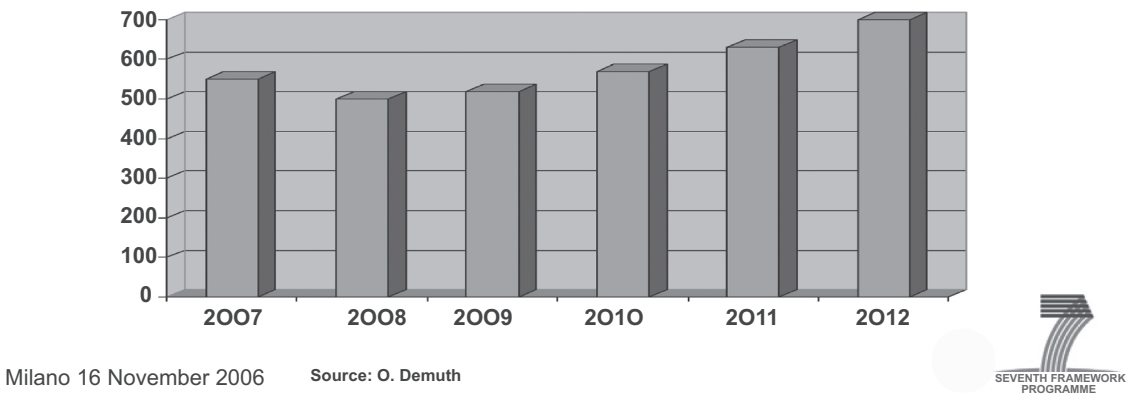

Figure 2 Provisional increase of nanotechnology.

These labile particles with diameters from 50 to $5000 \mathrm{~nm}$ are used to produce micro- or nanoemulsions capable of carrying and protecting active compounds from oxidation, and also improve their penetration through the skin layers ${ }^{9}$ (Figure 3).

One of the major factors that determines the ability of substances to penetrate the skin is the size of the molecule. According with Johann Wiechers, the role of a delivery system is to ensure that the right concentration of the right chemical is reaching the right site in the body for the correct period of time.${ }^{10}$ However, the efficiency of an active compound depends largely on its bioavailability - it is vital that it reaches the site of action and be released for a prolonged period of time.

To this end, recent extensive research has developed different nanotechnology oriented, controlled delivery

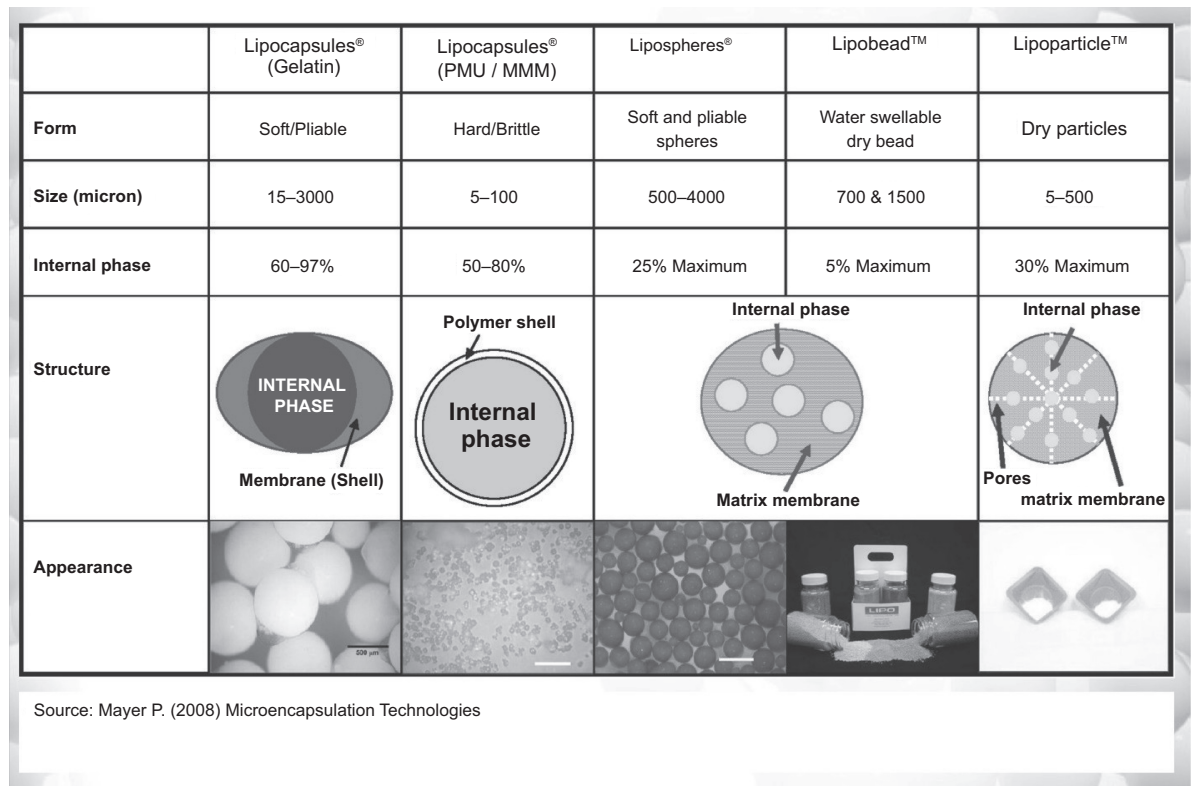

Figure 3 Types of delivery systems. Reproduced courtesy of Pat Meyer, Lipo Chemicals. 
systems, from the simplest to the most sophisticated ${ }^{10}$ (Figure 4).

Thus nanovesicles, as a skin delivery system, and solid lipid nanoparticles (SLN) or nanostructured lipid carriers (NLC), have been developed for cosmetic and pharmaceutical applications. ${ }^{11}$

Vesicles are hollow colloidal particles, consisting of amphiphilic molecules. Because of their amphiphilic properties, these molecules can, in the presence of water, form unilamellar or multilamellar vesicles. Both water-soluble and water-insoluble compounds can be entrapped in such vesicles and a wide variety of lipids and surfactants can be used to prepare them.

These vesicles might act: (a) as carriers to deliver entrapped molecules into or across the skin; (b) as penetration enhancers to modify the intercellular lipid lamellae; (c) as a depot for sustained release of active compounds; (d) as a site-limiting membrane barrier for a controlled transepidermal or transdermal delivery system.

In contrast to a vesicles-based delivery system, SLN and NLC have the great advantage of high stability. Moreover, these lipid carriers create a nanolayer lipid film on top of the skin, thereby avoiding water evaporation and thus increasing skin hydration.

Furthermore, the small size of all the nanostructured compounds ensures a closer contact with the stratum corneum, thus increasing the amount of incorporated active ingredients reaching the site of action. Wetting, spreading and penetration also may be enhanced as a result of the low surface tension of the whole system and the low interfacial tension of the oil/water $(\mathrm{O} / \mathrm{W})$ nanodroplets.

However, all the nanoparticles obtained from different emulsions have to be considered labile forms, because of the total disintegration of their components after application to the skin surface. Moreover, their mean dimension in cosmetic emulsions is about $100 \mathrm{~nm}$.

Another group of nanoparticles widely used in cosmetic dermatology and totally insoluble both in water and oil includes the inorganic physical UV filters titanium dioxide $\left(\mathrm{TiO}_{2}\right)$ and zinc oxide $(\mathrm{ZnO})$, considered sunscreen in the US and Japan, and in Germany only among the EU countries. These two substances are used in particles of 60 to $200 \mathrm{~nm}$ to obtain a transparent emulsion, thus increasing cosmetic compliance (Figure 5). Of note is that the miniaturization of these minerals increases not only their transparency, but also their filtering capacity, ${ }^{12}$ because of their higher reflective index.

Therefore, these minerals may be considered as broad-spectrum UV blockers when used in micronized form, becoming invisible after application to the skin ${ }^{13}$ (Figure 6). Additionally, the surface of these nanofilters may be coated with a neutral material such as silica, polysiloxane compounds, glass, or aluminium oxide, to improve their dispersion state, photostability and efficacy, eliminating direct contact with the skin (Figure 7) and increasing their margin of safety. ${ }^{14} \mathrm{As} \mathrm{TiO}_{2}$ is not only a UVA filter, but also an extremely efficient UVB filter, it shows by far the highest versatility of any sunscreen product. ${ }^{15}$

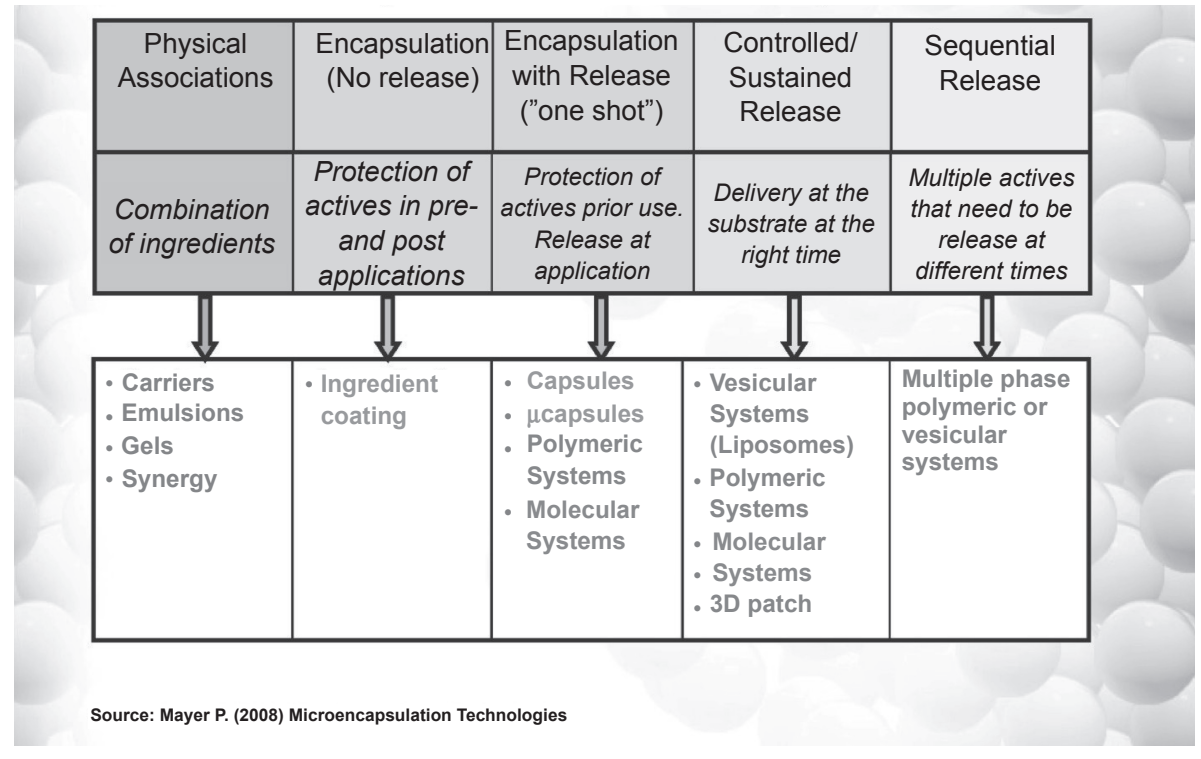

Figure 4 Delivery systems: from the simplest to the most complicated. Reproduced courtesy of Pat Meyer, Lipo Chemicals. 


\section{$\%$ transparency in consumer panel tests}

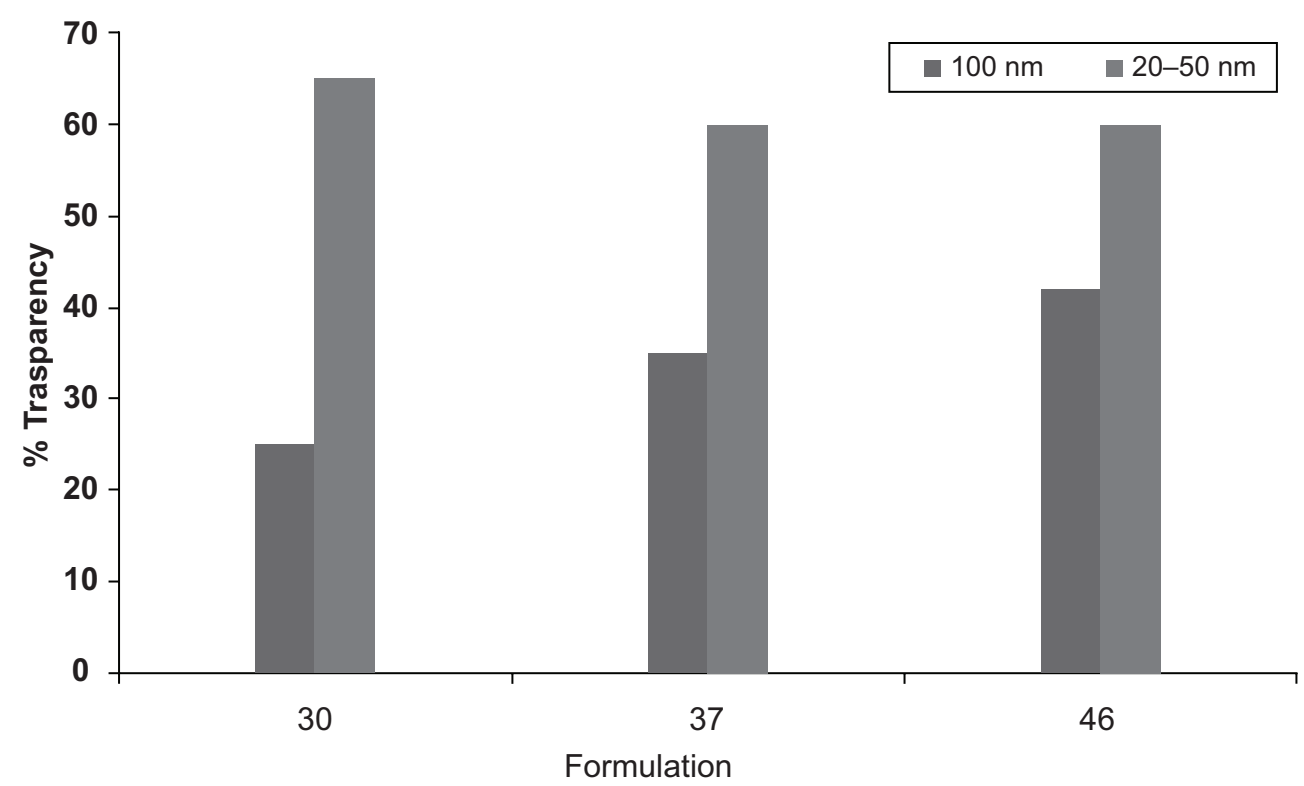

Figure 5 The level of transparency in consumer panel tests depending on the dimension of $\mathrm{ZnO} / \mathrm{T}_{\mathrm{i}} \mathrm{O}_{2}$ particles. Courtesy Antaria Limited.

Another important group of insoluble nanoparticles used in cosmetics are microcapsules. These are small particles containing an active agent or core material surrounded by a coating layer or shell. Their diameter may vary from 1 to $1000 \mu \mathrm{m}$; capsules smaller than $1 \mu \mathrm{m}$ are called nanocapsules and capsules larger than $1000 \mu \mathrm{m}$ are

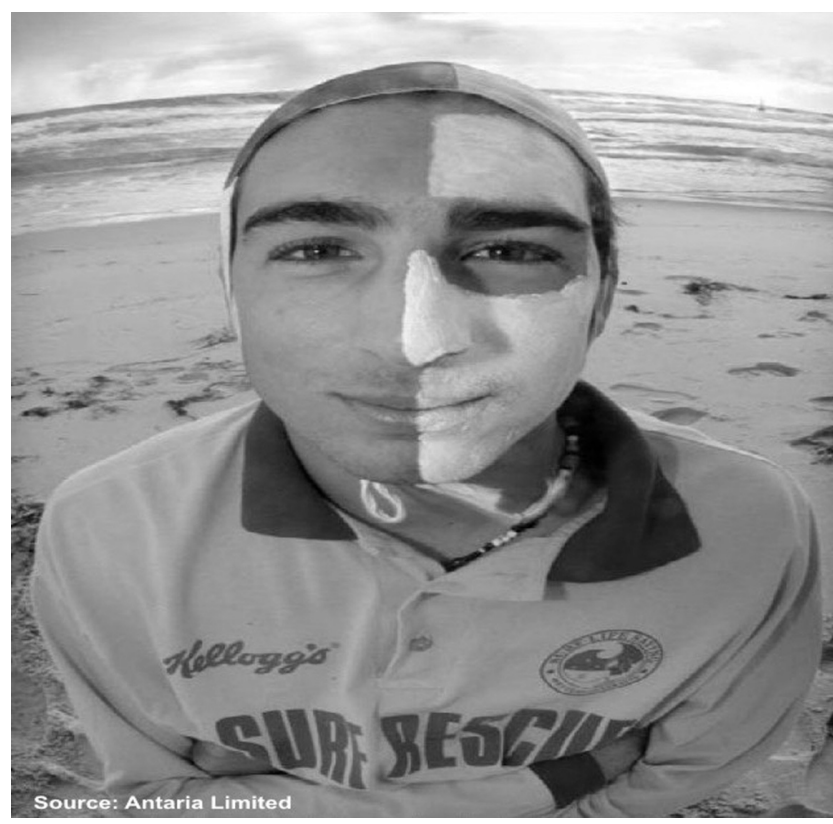

Figure $6 \mathrm{~A}$ face covered with standard $\mathrm{ZnO}$ (on the right, ie, subject's left side) or nano-size $\mathrm{ZnO}$ (on the left, ie, subject's right side). Reproduced courtesy of Geoff Trotter, Antaria Limited. called macrocapsules. ${ }^{16-18}$ Microcapsules may help to solve problems in cosmetic dermatology such as incompatibility of different ingredients, and protection of substances liable to oxidation or affected by atmospheric moisture.

The general outcome of EU discussions on the safety of nanomaterials in cosmetic dermatology indicates that some risks are inevitable, although conventional toxicological methodologies are not adequate to assess their safety. At present, these risks remain hypothetical because these discussion statements are not supported by documented research results. ${ }^{19-23}$ Recently the EU Parliament has passed a resolution on the regulatory aspect of nanomaterials, ${ }^{24}$ considering them necessary for EU citizens, if made and distributed in a responsible manner.

The EU Parliament has stressed the need for legislation that includes a more comprehensive science-based definition of nanomaterials, together with a clear assignment of liability to producers and employers arising from the use of nanomaterials, through all routes of exposure (such as inhalation and the skin).

Recent studies on the safety of nanomaterials for human health have led, for example, to false-positive or falsenegative results and conclusions because of shortcomings in applied protocols (Table 1). ${ }^{25-36}$ Thus the Commission on Nanoscience has provided a "Code of Conduct for all individuals and civil society organizations involved or interested in nanosciences and nanotechnologies (N\&N) research". ${ }^{37}$ 


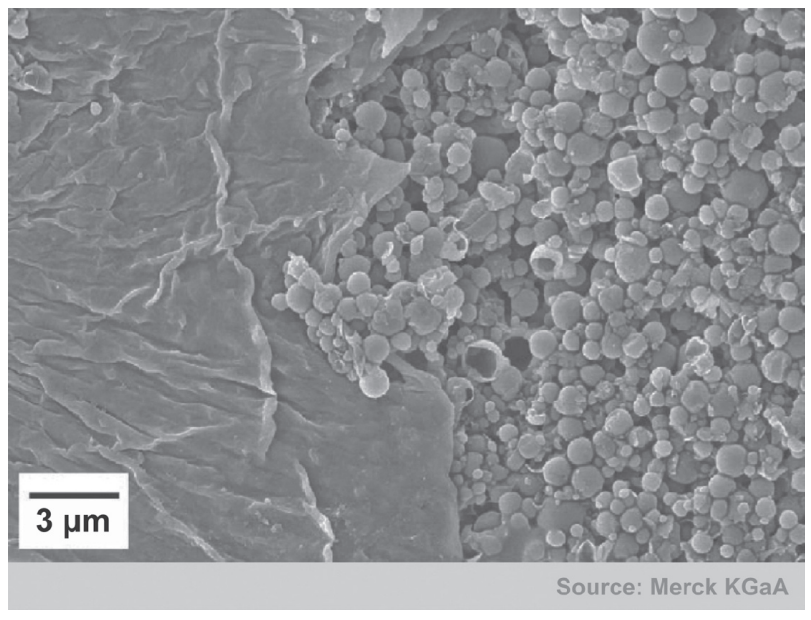

Figure 7 Sunscreen covered by glass at level of horny layer. Courtesy Merck KGaA.
This Code of Conduct aims to promote integrated, safe and responsible nanoscience and nanotechnology research in Europe for the benefit of society as a whole. Moreover the code must be considered complementary to existing regulations. Thus far nanobiotechnology seems to pose no special risks for medicine and pharmacology. ${ }^{38,39}$

However, nanotechnology is a very broad term, and most fears about human health arise as a result of the specific properties of nanomaterials and nanoparticles, whether natural or man-made. In fact, natural nanoparticles do occur in the environment, for example in waste matter, some of which are are not materials engineered by scientists..$^{39,40}$

One type of natural nanoparticle, chitin nanofibrils, are currently used by our research group as an active compound

Table I A review of the results of $\mathrm{TiO}_{2}$ and $\mathrm{ZnO}$ percutaneous absorption studies

\begin{tabular}{|c|c|c|c|c|}
\hline Test material & Particle size & Skin model/technique & Results & Reference \\
\hline $\begin{array}{l}\mathrm{TiO}_{2} \text { and } \mathrm{ZnO} \\
\text { (no information on coating) }\end{array}$ & $\begin{array}{l}\mathrm{TiO}_{2}: 50 \text { to } 100 \mathrm{~nm} \\
\mathrm{ZnO}: 20 \text { to } 200 \mathrm{~nm}\end{array}$ & Human skin, in vitro & $\begin{array}{l}\text { Penetration limited to upper layers } \\
\text { of stratum corneum }\end{array}$ & 27 \\
\hline $\begin{array}{l}\mathrm{TiO}_{2} \mathrm{Al}_{2} \mathrm{O}_{3} / \text { stearic acid } \\
\text { coated }\end{array}$ & $150 \mathrm{~nm}$ to $170 \mathrm{~nm}$ & Human subjects (biopsy) & $\begin{array}{l}\text { Particles on and in the upper layers } \\
\text { of stratum corneum. About I\% of particles } \\
\text { in the ostium of the follicle. No penetration } \\
\text { into living skin }\end{array}$ & 28 \\
\hline $\begin{array}{l}\text { Various } \mathrm{TiO}_{2} \text { anatase and } \\
\text { rutile, coated and uncoated } \\
\text { materials }\end{array}$ & $14 \mathrm{~nm}$ to $200 \mathrm{~nm}$ & $\begin{array}{l}\text { Pig and human skin } \\
\text { in vitro, human subjects } \\
\text { (skin stripping or biopsy) }\end{array}$ & $\begin{array}{l}\text { No penetration beyond the stratum } \\
\text { corneum in any study }\end{array}$ & 29 \\
\hline $\begin{array}{l}\mathrm{TiO}_{2}\left(\mathrm{SiO}_{2} \mathrm{Al}_{2} \mathrm{O}_{3}+\mathrm{SiO}_{2}\right. \\
\text { coated })\end{array}$ & $10 \mathrm{~nm}$ to $100 \mathrm{~nm}$ & Human skin, in vitro & $\begin{array}{l}\text { Penetration of particles into the upper } \\
\text { layers of stratum corneum. No penetration } \\
\text { into living skin }\end{array}$ & 30 \\
\hline $\begin{array}{l}\mathrm{TiO}_{2}\left(\mathrm{SiO}_{2}-\mathrm{Al}_{2} \mathrm{O}_{3} \mathrm{Al}_{2} \mathrm{O}_{3} l\right. \\
\left.\mathrm{SiO}_{2} \text { coated }\right)\end{array}$ & $10 \mathrm{~nm}$ to $100 \mathrm{~nm}$ & Human subjects (biopsy) & $\begin{array}{l}\text { Particles on or in the outmost surface of } \\
\text { the stratum corneum. No penetration into } \\
\text { living skin }\end{array}$ & 31 \\
\hline $\mathrm{TiO}_{2}$ (no coating) & $20 \mathrm{~nm}$ & Human skin, in vitro & $\begin{array}{l}\text { Penetration in restricted to the topmost } \\
3-5 \text { corneocyte layers in the stratum } \\
\text { corneum disjunctum. No penetration into } \\
\text { living skin }\end{array}$ & 32 \\
\hline $\begin{array}{l}\mathrm{TiO}_{2} \text { in various } \\
\text { formulations } \\
\text { (no information on coating) }\end{array}$ & $\begin{array}{l}\text { Needles: } 45 \text { to } \\
150 \mathrm{~nm} \times 17 \text { to } 35\end{array}$ & Pig skin, in vitro & $\begin{array}{l}\text { Particles on/in the stratum corneum; } \\
\text { minimal penetration into stratum } \\
\text { granulosum. No penetration into living skin }\end{array}$ & 33 \\
\hline $\mathrm{ZnO}$ & $15 \mathrm{~nm}$ to $30 \mathrm{~nm}$ & Human skin, in vitro & $\begin{array}{l}\text { Less than } 0.03 \% \text { of applied } \mathrm{Zn} \text { recovered in } \\
\text { the receptor solution, no particles detected } \\
\text { in epidermis or dermis }\end{array}$ & 34 \\
\hline $\begin{array}{l}\mathrm{TiO}_{2}\left(\mathrm{SiO}_{2} \text { or dimethicon }\right. \\
\text { coated) and } \mathrm{ZnO} \\
\text { (uncoated) }\end{array}$ & $\begin{array}{l}\mathrm{TiO}_{2}: 30 \text { to } 60 \mathrm{~nm} \\
\mathrm{ZnO}:<160 \mathrm{~nm}\end{array}$ & Pig skin, in vitro & $\begin{array}{l}\text { No penetration beyond stratum corneum. } \\
\text { Receptor solution recoveries of } 0.8 \%-1.4 \% \\
\text { of applied dose }\end{array}$ & 35 \\
\hline $\begin{array}{l}\mathrm{TiO}_{2} \text { in a sunscreen } \\
\text { formulation, silicone coated }\end{array}$ & $20 \mathrm{~nm}$ & $\begin{array}{l}\text { Human skin in vitro } \\
\text { and human subjects, } \\
\text { skin stripping,TEM, } \\
\text { backscattering } \\
\text { spectometry }\end{array}$ & $\begin{array}{l}\text { Penetration limited to upper layers } \\
\text { of stratum corneum. No penetration } \\
\text { in skin furrows or follicular opening } \\
\text { may be mistaken for penetration in the } \\
\text { epidermal compartment }\end{array}$ & 36 \\
\hline
\end{tabular}


in cosmetic dermatology. Research results obtained to date suggest this particle poses no risks to consumers but offers numerous benefits. ${ }^{41,42}$

\section{Chitin nanofibril}

A chitin nanofibril is a nanocrystal of a natural polysaccharide obtained from the crustacean exoskeleton after elimination of the carbonate and protein portions. Having a backbone like hyaluronic acid, chitin nanofibrils are easily metabolized by the body's endogenous enzymes and thus is used in cosmetic dermatology and biotextiles. The crystal is so named because its average size is $240 \times 7 \times 5 \mathrm{~nm}$ (nano), and because it is shaped like a thin needle (fibril). Moreover, because it occurs naturally and is considered a safe raw material, it is safe to use. As it is easily metabolized by enzymes, it is both bio- and eco-compatible. As the nanofibril has an average size one-quarter that of a bacterium, $1 \mathrm{~g}$ of the product covers a surface area of $400 \mathrm{~m}^{2} .{ }^{43,44}$ Many studies have shown that chitin nanofibrils can activate the proliferation of keratinocytes as well as fibroblasts, regulating not only collagen synthesis but also cytokine secretion and macrophage activity. ${ }^{45,46}$

Our group has obtained interesting results showing how chitin nanofibrils can ameliorate not only the appearance of photoaged skin ${ }^{47-51}$ but also promote wound healing by reducing hypertrophic scar formation ${ }^{52,53}$ (Figure 8). In vitro studies have shown how chitin nanofibrils can increase the reproduction of fibroblasts with a subsequent increase in collagen synthesis and in adenosine triphosphate production. In an in vivo double-blind study, skin hydration and superficial skin lipids were improved, with a simultaneous reduction in lipid peroxides and transepidermal water loss. ${ }^{49-51}$ By using different types of emulsions, chitin nanofibrils have an interesting wound healing activity. ${ }^{52,53}$ Healthy biotextiles have also been produced..$^{54}$

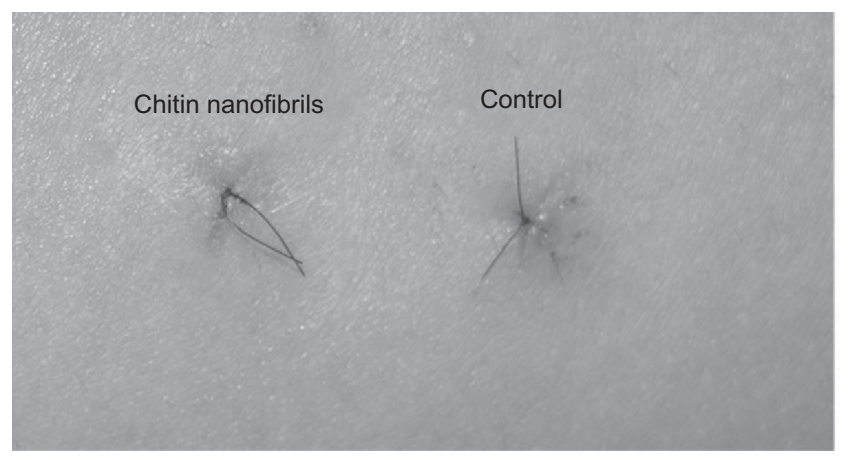

4 days post treatment
Research efforts in cosmetic dermatology are currently aimed at developing new environmentally friendly nanosized chemicals and new nanoparticulate systems for the skin. Therefore, during recent years several delivery systems have been developed (visible beads, microcapsules, nanocapsules and liposomes, or lipid nanoparticles, SLN) for the cosmetic and dermatological industry, and successively introduced into many marketed products. Many different active components can be encapsulated in these delivery systems, such as vitamins fragrances, botanical extracts, and drugs, which have a wide range of cosmetic or dermatological properties.

Some of these delivery systems, such as SLN, are innovative drug carrier systems first designed for intravenous administration and more recently investigated for peroral and transdermal applications in cosmetic dermatology. Thus, chemically labile agents should be protected from degradation and the release profile modulated. The much higher surface-to-mass ratio of nanomaterials should increase the efficacy of many active compounds.

In conclusion it is necessary to understand better the potential of these new technologies, so that the potential negative effects of their chemistry on human health and the environment may be minimized or avoided.

Nanoscience and nanoengineering could significantly improve our understanding of nanoscale processes at the molecular level that occur in the environment. Consequently it should be possible to develop new green technologies that minimize the production of undesirable byproducts released into the environment, into waste sites and streams for example. ${ }^{55}$ Nevertheless, to speed up the development of both nanotechnology and nanobiotechnology, multidisciplinary teams of highly trained people with backgrounds in biology, medicine, applied and computational mathematics, physics, chemistry, and electrical, chemical and mechanical engineering will be needed. Despite the current international

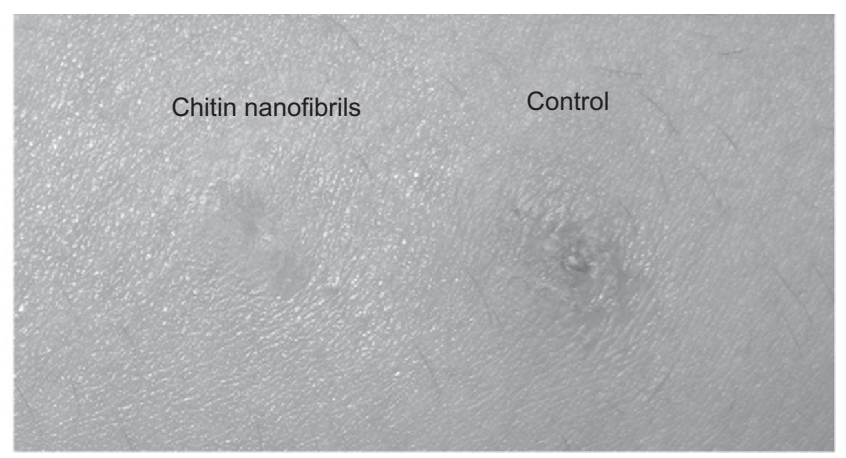

20 days post treatment

Figure 8 Wound healing activity of chitin nanofibrils. 


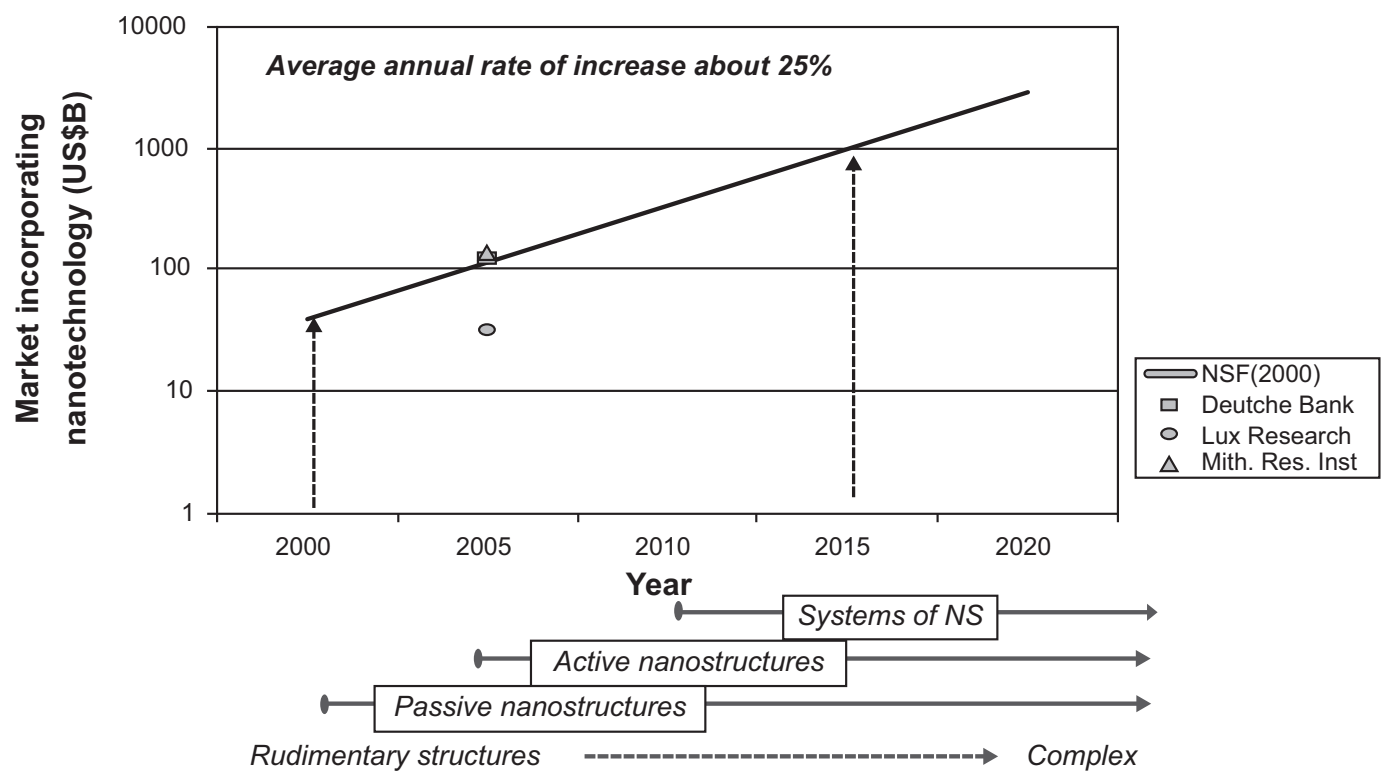

Source: Italian working group on Nanotechnology - 2009

Figure 9 Estimated economic impact of nanotechnologies.

financial crisis, nanotechnology and innovative cosmetic dermatology, may have the potential to help reinvigorate a nation's economy (Figure 9). However, apart from helping to overcome some new challenges in molecular imaging techniques, quantitative analytical tools, physical models of the cell as a machine, better in vivo tests and better drug/ cosmetic delivery systems, nanotechnology could play an important role in the sustainability of not only cosmetic dermatology but also of agriculture, water filtering, energy materials, and a clean environment.

In conclusion, the most complex and highly functional nanoscale systems have been invented by nature. We have to find ways of how to best use them for ameliorating our wellbeing and the environment. Thus, nano-products should be designed and sold in a way that fully respects the health of consumers and the environment. Both nanotechnology and biotechnology have the potential to revolutionize both our industries and way of life. They represent the key technologies of the twenty-first century, offering excellent opportunities for both research and business.

\section{Disclosure}

The author declares no conflicts of interest.

\section{References}

1. Morganti P, Morganti G, Yuanhong Li. Nanostructured products: technology and future. J Appl Cosmetol. 2007;25(4):161-178.

2. Morganti P, Morganti G. Nanotechnology and wellness. SÖFW Journal. 2007;133(5):22-27.
3. Morganti P, Morganti G, Muzzarelli R, et al. Chitin nanofibrils: a natural compound for innovative Cosmeceuticals. Cosmetics and Toiletries. 2007; 122 (4):81-88.

4. Morganti P, Morganti G. Fabricating a good treatment. Soap Perfumery and Cosmetics. 2007:85-86.

5. Morganti P. Applied Nanotechnology in cosmetic and functional food. Eucocosmetics. 2007;2:12-15.

6. Morganti P, Chen HD, Gao XH, Li Y, et al. Nanoscience the challenging cosmetics healthy food and biotextiles SÖFW Journal. 2009;135(4):2-7.

7. Nanotechnology Commission. ISO/TC 229, 2009, 24 March.

8. Schueller R, Romanowski P. Emerging Technologies and the future of cosmetic science. In: Schueller R, Romanowski P editors, Beginning Cosmetic Chemistry, 3rd ed. Coral Stream IL, USA: Allured Publ. Co; 2009:427-434.

9. Mayer P. Microencapsulation technologies. PCHI, Proceedings, Shanghai, March 17-19, 2008:15-22.

10. Wiechers JW. Science and Applications of Skin delivery Systems. Coral Stream, IL, USA Allured Publ. Co; 2008.

11. Souto EB, Müller RH. Challenging Cosmetics-Solid Lipid Nanoparticles (SLN) and Nanostructured Lipid Carriers (NLC). In: Wiechers JW editor, Science and Application of Skin Delivery Systems. Allured Publ. Co: IL , USA, Coral Stream; 2008:227-250.

12. Morganti P. Meccanismo d'azione dei prodotti cosmetici: miti e realta'. Presented at Giornata di studio: Prodotti Cosmetici. Approfondimenti e proposte su regolamentazione, sicurezza e mercato. Milano 2009, 29-Gennaio.

13. Hides L, Trotter G. A new paradigm in mineral UVA and UVB protection. Presented at PCHI Shanghai meeting, 2008, March 17-19.

14. Nasu A, Otsubo Y. Rheology and UV protection properties of suspension of fine titanium dioxide in silicon oil. $J$ Cabloid Interfacial Sci. 2006;296:558-564.

15. Pflücker F, Bunger J, Hitzel S, Vitte J, et al. Complete Photoprotectiongoing beyond visible endpoints. SÖFW Journal. 2005;131(7):20-30.

16. Vinetsky Y, Magdassi S. Microcapsules in cosmetics. In: Magdassi S, Touitou E. Novel Cosmetic Delivery Systems. New York: Marcel Dekker Inc; 1999:295-313.

17. Royal Society and Royal Academy of Englneering nanoscience and nanotechnologies, opportunities and uncertainties, 2004. URL www. royalsoc.uk/policy/.2004 
18. Dreyler K. The future of nanotechnology: molecular manufacturing. 2003. URL www.eurekartet.org/context. $\mathrm{p}^{4} \mathrm{p}^{2}$.context=nano\&slow=essays.

19. SCCP Scientific Committee on Consumer Products. Preliminary opinion on safety of nanomaterials in cosmetic products; 2007.

20. Ball P. Nanotechnology in the firing line. 2003. URL http://nanotechweb. org/cws/article/indepht/18804.

21. Dreher K. Health risk assessment of manufactured nanomaterials: more than just size. Nanotechnology for Remediation Technical Workshop, National Health and Environmental Effects Laboratory, US Environmental Protection Agency, 2005; Washington, USA.

22. Oberdoester G, Oberdoester E, Oberdoester J. Nanotoxicology: an emerging discipline evolving from studies of ultrafine particles. Environ Health Perspect. 2005;113(7):823-839.

23. Colvin V. Physical properties of nanomaterials. Towards predictive assessments of risk, international nanomaterial environmental health and safety research needs assessment- Workshop 1: US national institute of health, 2007, USA. URL http://cohesion.rice.edu/CentersAndlnst// CON/emplibrary/ColvinRNADJan2007.pdf

24. European Parliament resolution of 24 April 2009 on regulatory aspect of nanomaterials. Available from: URL http://www.europarl. europa.eu/sides/getDoc.do?pubRef=-//EP//TEXT+TA+P6-TA-2009$0328+0+\mathrm{DOC}+\mathrm{XML}+\mathrm{V} 0 / / \mathrm{EN}$

25. Nohynek GJ, Lademann J, Ribaud C, et al. Grey goo on the skin? Nanotechnology, cosmetic and sunscreen safety, Crit Rev Toxicol. 2007;37(3):251-277.

26. Stern ST, McNeil SE. Nanotechnology safety concerns revisited. Review Toxicol Sci. 2008;101:4-21.

27. Dussert AS, Gooris E. Characterisation of the mineral content of a physical sunscreen emulsion and its distribution onto human stratum corneum. Int J Cosmet Sci. 1997;19:119-129.

28. Lademann J, Weigmann HJ, Rickmeier CH, et al. Penetration of titanium dioxide microparticles in a sunscreen formulation into the horny layer and the follicular orifice. Skin Pharmacol Appl Skin Physiol. 1999;2:247-256.

29. SCCNFP. Opinion of the Scientific Committee on Cosmetic Products and Non-Food Products Intended for Consumers Concerning Titanium Dioxide, 2000. Brussels, Belgium: European Commission. URL http://ec.europa.eu/health/ph_risk/committees/04_ scp/04_sccp_en.htm.

30. Pluecker F, Wendel V, Hohenberg H, et al. The human stratum corneum layer: An effective barrier against dermal uptake of different forms of topically applied micronized titanium dioxide. Skin Pharmacol Appl Skin Physiol. 2001;14(Suppl 1):92-97.

31. Schulz J, Hohenberg F, Pluecker F, et al. Distribution of sunscreens on skin. Adv Drug Deliv Rev. 2002;54(Suppl 1):S157-S163.

32. Butz T Dermal penetration of nanoparticles: what we know and what we don't. Cosmetic. Science Conference Proceedings, Munich. SÖFW Journal. 2009;135(4):8-10.

33. Menzel F, Reinet T, Vogt J, Butz T. Investigations of percutaneous uptake of ultrafine $\mathrm{TiO}_{2}$ particles at the high energy ion nanoprobe LIPSION. Nucl Instrum Methods Phys Res B. 2004:219-220.

34. Cross SE, Innes B, Roberts MS, Tsuzuki T, Robertson TA, McCormick P. Human skin penetration of sunscreen nanoparticles: In vitro assessment of a novel micronized zinc oxide formulation. Skin Pharmacol Physiol. 2007;20:148-154.
35. Gamer A, Leibold E, van Ravenzwaay B. The in vitro absorption of microfine $\mathrm{ZnO}$ and $\mathrm{TiO}_{2}$ through porcine skin. Toxicol In Vitro. 2006;20(3):301-307.

36. Mavon A, Miquel C, Lejune O, Payre B, Moretto P. In vitro percutaneous absorption and in vivo stratum corneum distribution of an organic and a mineral sunscreen. Skin Pharmacol Physiol. 2007; 20:10-20.

37. Commission of the European Communities. Commission Recommendation on a Code of Conduct for responsible nanosciences and nanotechnologies research. Brussels. 07/02/2008 C, 2008, 424 final.

38. EMEA Reflection paper on nanotechnology-based products for human use, 2006. EMEA/CHMP/79769/2006.

39. Nohynek GJ. Nano-cosmetics. No health risk. Cossma. 2007;3: 10-11.

40. Starzyk E, Frydrych A, Solyga A. Nanotechnology: does it have a future in cosmetics? SÖFW Journal. 2008;134(6):42-52.

41. Morganti P, Muzzarelli RAA, Muzzarelli C. Multifunctional use of innovative chitin nanofibrils for skin care. J Appl Cosmetol. 2006;24: $105-114$.

42. Morganti P, Morganti G. Chitin nanofibrils for advanced cosmeceutical. Clin Dermatol. 2008;26:334-340.

43. Muzzarelli RAA, Chitin and its derivates: new trends off applied research. Carbohydr Polym. 1993;3:53-75.

44. Percot A, Viton C, Domard A. Optimization of chitin extraction from shrimp shell. Biomacromolecules. 2003;4:8-18.

45. Muzzarelli RAA, Mattioli-Belmonte M, Pugnaloni A, et al. Biochemistry, histology and clinical uses of chitins and chitosans in wound healing. In: Jollés P, Muzzarelli RAA, editors. Chitin and Chitinases. Basel, Swizterland: Birkhaüser Verlag; 1999:251-264.

46. Muzzarelli RAA, Muzzarelli C. Chitin nanofibrils. In: Dutta PK, editor. Chitin and Chitosan: Research Opportunities and Challenges. Contai, India: SSM International Publication; 2005:129-146.

47. Morganti P, Fabrizi G, Bruno C. Protective effects of oral antioxadants on skin and eye function. Skinmed. 2004;3(6):310-316.

48. Biagini G, Zizzi A, Giantomassi F, et al. Cutaneous absorption of nanostructured chitin associated with natural synergistic molecules (lutein). J Appl Cosmetol. 2008;26:69-80.

49. Morganti P, Fabrizi G, Palombo P, et al. Chitin-nanofibrils: a new active cosmetic carrier. J Appl Cosmetol. 2008;26:105-120.

50. Morganti P, Morganti G, Fabrizi G, et al. A new sun to rejuvenate the skin. J Appl Cosmetol. 2008;26:159-166.

51. Morganti P, Fabrizi G, Ruocco E, et al. Chitin nanofibrils improved photoprotection. Cosmetics and Toiletries. 2009;124(9):66-73.

52. Biagini G, Zizzi A, Tucci G, et al. Chitin nanofibrils linked to chitosan glycolate as spray, gel and gauze preparations for wound repair. J Bioact Compat Polym. 2007;22:525-538.

53. Mezzana P. Clinical efficacy of a new chitin-nanofibrils based gel in wound healing. Acta Chirurgiae Plasticae. 2008;50(3):81-84.

54. Morganti P. Leather and textile chemicals: chitin nanofibrils in textiles. Speciality Chemicals Magazine. 2008;28(9):26.

55. Yzer C, Venkatesh MN. VFA and FBAE position papers on nanobiotechnology. 2009. URL www.FBAE.org and www.VFA.de
Clinical, Cosmetic and Investigational Dermatology

\section{Publish your work in this journal}

Clinical, Cosmetic and Investigational Dermatology is an international, peer-reviewed, open access, online journal that focuses on the latest clinical and experimental research in all aspects of skin disease and cosmetic interventions. All areas of dermatology wil be covered; contributions will be welcomed from all clinicians and

\section{Dovepress}

basic science researchers globally. This journal is indexed on CAS The manuscript management system is completely online and includes a very quick and fair peer-review system, which is all easy to use. Visit http://www.dovepress.com/testimonials.php to read real quotes from published authors. 